http://dx.doi.org/10.11646/phytotaxa.127.1.8

\title{
Three new Psammothidium species from lakes of Olympic and Cascade Mountains in Washington State, USA
}

\author{
MIHAELA D. ENACHE ${ }^{1}$, MARINA POTAPOVA ${ }^{1}$, RICH SHEIBLEY $^{2} \&$ PATRICK MORAN $^{2}$ \\ ${ }^{I}$ Academy of Natural Sciences, 1900 Benjamin Franklin Parkway, Philadelphia, PA, 19103 \\ Email: mihaela.enache@dep.state.nj.us (correspondingauthor) \\ ${ }^{2}$ U.S. Geological Survey, Washington Water Science Center, 934 Broadway, Suite 300, Tacoma, WA 98402
}

\begin{abstract}
Populations of several Psammothidium species were found in core sediments from nine remote, high elevation, ultraoligotrophic and oligotrophic, Olympic and Cascade Mountain lakes. Three of these species, P. lacustre, P. alpinum, and $P$. nivale, are described here as new. The morphology of the silica frustules of these species was documented using light and scanning electron microscopy. We discuss the similarities and differences with previously described Psammothidium species.
\end{abstract}

Key words: diatom, lake sediments, alpine lakes, LM, SEM

\section{Introduction}

Diatom assemblages were analyzed in core sediments from nine Washington Cascade Mountains lakes. These lakes were selected by the U.S. Geological Survey (USGS) for a paleolimnological investigation of the impact of inorganic nitrogen atmospheric deposition on lake biogeochemistry. However, these lakes are still generally considered oligotrophic systems.

Species of Psammothidium Bukhtiyarova \& Round (1996: 3) are very abundant (up to $28 \%$ relative abundance) and diverse in study lakes and they were investigated with both light (LM) and scanning electron microscopy (SEM). Psammothidium was separated from Achnanthidium Kützing (1844: 75) by Bukhtiyarova \& Round (1996) to designate adnate taxa commonly attached to sand grains by the raphe valve face, as opposed to Achnanthidium species, which are more common on stable surfaces such as rocks and plants and found attached via short mucilaginous stalks. Bukhtiyarova \& Round (1996) pointed out that the major morphological differences between Psammothidium and Achnanthidium are (1) the shape of the valve, oval-elliptic as opposed to linear/linear-capitate; (2) the convex flexure of the raphe valve as opposed to concave in Achnanthidium; (3) striae reaching the sternum as opposed to marginal in Achnanthidium; and (4) raphe fissures located in a central channel (or near the valve center) as opposed to non-channeled with pin-hole central endings in Achnanthidium (Bukhtiyarova \& Round 1996).

Among Psammothidium species occurring in the study lakes, based on silica frustule morphological characteristics, three species are new to science. Here we describe those new species using light (LM) and scanning electron microscopy (SEM) observations.

\section{Material and Methods}

Sediment cores were collected by USGS crews in the summer of 2009 from nine lakes in Olympic, North Cascades, and Mt. Rainier national parks, located at a minimum elevation of $1335 \mathrm{~m}$. A summary of lake physical characteristics is given in Table 1. Cores were collected by boat from the deepest portion of each lake using a Uwitec gravity corer (http://www.uwitec.at/). 
TABLE 1: Physical properties of study lakes. OLYM—Olympic National Park, NOCA—North Cascades National Park, MORA—Mt. Rainier National Park.

\begin{tabular}{lcccc}
\hline \multicolumn{1}{c}{ Study Lake } & Park & Elevation $(\mathrm{m})$ & Area $(\mathrm{ha})$ & Max. Depth $(\mathrm{m})$ \\
\hline Eunice Lake & MORA & 1640 & 5.32 & 10.05 \\
Snow Lake & MORA & 1438 & 2.39 & 9.75 \\
Copper Lake & NOCA & 1600 & 5.14 & 21.03 \\
Hidden Lake & NOCA & 1835 & 24.98 & 61.56 \\
Stiletto Lake & NOCA & 2066 & 0.03 & 25.9 \\
Thornton Lake & NOCA & 1384 & 22.65 & 31.69 \\
Heather Lake & OLYM & 1589 & 0.40 & 7.01 \\
Hoh Lake & OLYM & 1335 & 7.40 & 14.93 \\
Milk Lake & OLYM & 1435 & 1.10 & 11.88 \\
\hline
\end{tabular}

Diatom slides were prepared using strong acid digestions in a microwave (CEM model MDS-21 00) with enclosed vessels, and temperature and pressure monitoring and control systems. Diatom-coated coverslips were mounted on glass slides using Naphrax ${ }^{\mathrm{R}}$ mounting medium (http://diatom.ansp.org/nawqa/ protocols.asp). Diatom species were investigated in core top (0-0.5-cm depth) and bottom sediments, and in an additional interval from Snow Lake $(2-2.5 \mathrm{~cm})$.

A Zeiss Axio Imager microscope equipped with AxioCam MRm digital camera was used for LM. For SEM, cleaned material was dried on aluminum stubs, which were sputter-coated with Pt-Pd and observed with a Zeiss Supra 50 VP FE SEM (Carl Zeiss, Jena, Germany) at an accelerating voltage of $10 \mathrm{kV}$. Terminology used to describe valve structure follows Anonymous (1975), Bukhtiyarova \& Round (1996) and Round et al. (1990).

Water samples for nutrient analysis were collected and processed according to methods outlined in the USGS National Field Manual (US Geological Survey, 2006; Wilde et al., 2004). Water chemistry measurements indicated that the study lakes are ultraoligotrophic or oligotrophic (Table 2).

TABLE 2: Water chemistry of study lakes from surface water collections, 2009. * Sample date also represents sediment core collection date.

\begin{tabular}{|c|c|c|c|c|c|c|}
\hline LAKE NAME & $\begin{array}{c}\text { Sample } \\
\text { Date* }\end{array}$ & $\begin{array}{l}\text { Total- } N \\
\left(\mathrm{mgL}^{-1}\right)\end{array}$ & $\begin{array}{l}\text { Total-P } \\
\left(\mathrm{mgL}^{-1}\right)\end{array}$ & $\begin{array}{l}\text { PO4-P } \\
\left(\mathrm{mgL}^{-1}\right)\end{array}$ & $\begin{array}{l}N O 3-N+N O 2-N \\
\left(\mathrm{mgL}^{-1}\right)\end{array}$ & $\begin{array}{l}\text { NH3-N } \\
\left(\mathrm{mgL}^{-1}\right)\end{array}$ \\
\hline Snow Lake & $10 / 7 / 2009$ & $<0.01$ & $<0.003$ & $<0.003$ & $<0.003$ & $<0.01$ \\
\hline Eunice Lake & $11 / 4 / 2009$ & 0.25 & 0.012 & $<0.003$ & 0.002 & $<0.01$ \\
\hline Hoh Lake & $9 / 8 / 2009$ & 0.16 & 0.007 & $<0.003$ & $<0.003$ & $<0.01$ \\
\hline Heather Lake & $9 / 10 / 2009$ & 0.06 & 0.005 & $<0.003$ & 0.007 & $<0.01$ \\
\hline Milk Lake & $9 / 11 / 2009$ & 0.04 & 0.004 & $<0.003$ & $<0.003$ & $<0.01$ \\
\hline Stiletto Lake & $8 / 26 / 2009$ & 0.27 & 0.007 & $<0.003$ & 0.006 & $<0.01$ \\
\hline Copper Lake & $9 / 22 / 2009$ & 0.07 & 0.004 & $<0.003$ & $<0.003$ & $<0.01$ \\
\hline Lower Thornton Lake & $9 / 23 / 2009$ & 0.10 & 0.003 & $<0.003$ & 0.004 & $<0.01$ \\
\hline Hidden Lake NOCA & $9 / 24 / 2009$ & 0.05 & 0.002 & $<0.003$ & $<0.003$ & $<0.01$ \\
\hline
\end{tabular}

\section{Results and Discussion}

The following Psammothidium species were identified in core sediments from study lakes: P. marginulatum (Grunow in Cleve \& Grunow) Bukhtiyarova et Round (1996: 5), P. helveticum (Hustedt) Bukhtiyarova et Round (1996: 8), P. subatomoides (Hustedt in Schmidt et al.) Bukhtiyarova et Round (1996: 13-14), $P$. scoticum (Flower et Jones) Bukhtiyarova et Round (1996: 22), P. curtissimum (Carter) Aboal in Aboal, Alvarez-Cobelas, Cambra \& Ector (2003:171), P. altaicum Bukhtiyarova in Bukhtiyarova et Round (1996: 5), P. lacustre sp. nov., P. alpinum sp. nov., and $P$. nivale sp. nov. 
The number of Psammothidium species in core top sediments was higher than in bottom sediments. For example, $P$. marginulatum was observed in bottom sediments from four lakes versus top sediments from seven lakes, while $P$. helveticum was observed in bottom sediments from five lakes versus top sediments from seven lakes (Table 3 ). The most abundant species across all study sites were $P$. curtissimum (maximum relative abundance $28 \%$ ) and $P$. scoticum (maximum relative abundance $22 \%$ ). The new species ( $P$. lacustre sp. nov., $P$. alpinum sp. nov., and $P$. nivale sp. nov) were found in core material from six lakes: Hidden Lake NOCA, Eunice, Snow, Stiletto, Hoh, and Copper lakes.

TABLE 3: Relative abundance (\%) of Psammothidium species identified in lake sediment samples from the Olympic and Cascade Mountains. $P$. cur $=P$. curtissimum; $P$. hel $=P$. helveticum; $P$. mar $=P$. marginulatum; $P$. scot $=P$. scoticum; $P$. sub $=$ P. subatomoides; $P$. lac $=$ P. lacustre sp. nov.; $P$. alp $=P$. alpinum sp. nov.; P. niv $=P$. nivale sp. nov.

\begin{tabular}{|c|c|c|c|c|c|c|c|c|c|c|}
\hline & ANSP Code & Interval $(\mathrm{cm})$ & P. cur & P. hel & P. mar & P. scot & P. sub & P. lac & P. alp & P. niv \\
\hline Snow L. & WACA001 & $0-0.5$ & 5.4 & 0.6 & 0.8 & 1 & 2.2 & 0.4 & 0 & 0 \\
\hline Snow L. & WACA002 & $28-29$ & 4.8 & 2 & 0 & 15 & 1 & 1 & 0 & 0 \\
\hline Snow L. & WACA019 & $2-2.5$ & 11.4 & 1 & 2.2 & 2.6 & 3.6 & 1.2 & 0.1 & 0.1 \\
\hline Eunice L. & WACA003 & $0-0.5$ & 7.2 & 0.6 & 0.8 & 11.6 & 5 & 1 & 0 & 0 \\
\hline Eunice L. & WACA004 & $39-40$ & 2.4 & 0 & 0.4 & 8.4 & 2 & 2.2 & 0 & 0 \\
\hline Hoh L. & WACA005 & $0-0.5$ & 0 & 0 & 0.4 & 0 & 0 & 0 & 0 & 0 \\
\hline Hoh L. & WACA006 & $37-38$ & 0 & 0 & 0 & 0 & 0 & 0 & 0 & 0 \\
\hline Heather L. & WACA007 & $0-0.5$ & 0 & 0 & 0 & 0 & 0 & 0 & 0 & 0 \\
\hline Heather L. & WACA008 & $17-18.5$ & 0 & 0 & 0 & 0 & 0 & 0 & 0 & 0 \\
\hline Milk L. & WACA009 & $0-0.5$ & 0 & 0.2 & 0 & 0 & 0 & 0 & 0 & 0 \\
\hline Milk L. & WACA010 & $37-38$ & 0 & 0 & 0 & 0 & 0 & 0 & 0 & 0 \\
\hline Stiletto L. & WACA011 & $0-0.5$ & 11.8 & 0.2 & 0.8 & 2.6 & 2.4 & 0.6 & 0 & 0 \\
\hline Stiletto L. & WACA012 & $30-31$ & 28.2 & 1 & 0.2 & 4 & 0.8 & 0 & 0 & 0 \\
\hline Copper L. & WACA013 & $0-0.5$ & 4.4 & 6 & 0.4 & 6.6 & 9 & 0 & 0 & 0 \\
\hline Copper L. & WACA014 & $38-39$ & 5.8 & 2 & 1.2 & 8.8 & 3.6 & 0.8 & 0 & 0 \\
\hline Lower Thornton L. & WACA015 & $0-0.5$ & 0.6 & 5.8 & 0.8 & 7.8 & 1.4 & 0 & 0 & 0 \\
\hline Lower Thornton L. & WACA016 & $15-16$ & 0.8 & 5.6 & 0 & 9.4 & 0.8 & 0 & 0 & 0 \\
\hline Hidden L. & WACA017 & $0-0.5$ & 11.6 & 6.4 & 4.4 & 9.8 & 4.6 & 0 & 1.2 & 0.1 \\
\hline Hidden L. & WACA018 & $34-35$ & 6.8 & 13.6 & 4.8 & 21.8 & 7.2 & 2 & 2.8 & 0 \\
\hline
\end{tabular}

\section{New species description}

\section{Division Bacillariophyta}

Class Bacillariophyceae Haeckel 1878 emend. D.G. Mann in Round et al. 1990

Order Achnanthales Silva 1962

Genus Psammothidium Bukhtiyarova \& Round (1996: 3)

Psammothidium lacustre Enache \& Potapova sp. nov. (Figs 1-8, 35-39)

Valvae lanceolate, 8.4-11.2 $\mu$ m latae, 16.7-28 $\mu$ m longae. Raphovalva cum area axialis linearis versus centro expanso, area centralis rectangularis, 1/2 vel 2/3 valvae lata. Raphe recta poris centralibus simples cum cristae et sulci, interne paulo curvatae. Fissuris terminalibus simplex, longae, ad versum curvatae. Araphovalva cum area axialis angusta, area centralis circulare, 2/3 valvae lata. Striae transapicales radiatae 22-26 in $10 \mu \mathrm{m}$; areolae cum foramina externae circulares, foramina internae transapicalem elongatae, 40-60 in $10 \mu \mathrm{m}$. 
Valves lanceolate, 8.4-11.2 $\mu \mathrm{m}$ wide, 16.7-28 $\mu \mathrm{m}$ long. Raphe valve with linear axial area, rectangular central area, occupying $1 / 2$ to $2 / 3$ of valve breadth (Figs 2, 3, 6, 7). Proximal raphe endings slightly deflected internally (Fig. 36). Terminal raphe fissures simple, long, deflected in opposite directions (Figs 2, 3, 6). Rapheless valve with narrow axial area, round central area occupying $2 / 3$ of the valve breadth (Figs 1, 4, 5, 8). Striae radiate, $22-26$ in $10 \mu \mathrm{m}$; areolae 40-60 in $10 \mu \mathrm{m}$, with round external foramina, and internal openings elongated transapically on both valves (Figs 35-39).

Type:-USA. Washington: Cascade Mountains, Snow Lake, $46.7576^{\circ} \mathrm{N}, 121.6982468^{\circ} \mathrm{W}$, lake sediment $(2-2.5$-cm depth core interval; lake maximum depth $9.75 \mathrm{~m}$ ), collected 07 October 2009, collection WACA019, (Circled specimen (Figs 1,2) on slide GC64860, accession \#GC64860 (ANSP!), holotype, designated here; circled specimens on slide GC64861 (ANSP!) and slide 84222 (CANA!), isotypes, designated here).
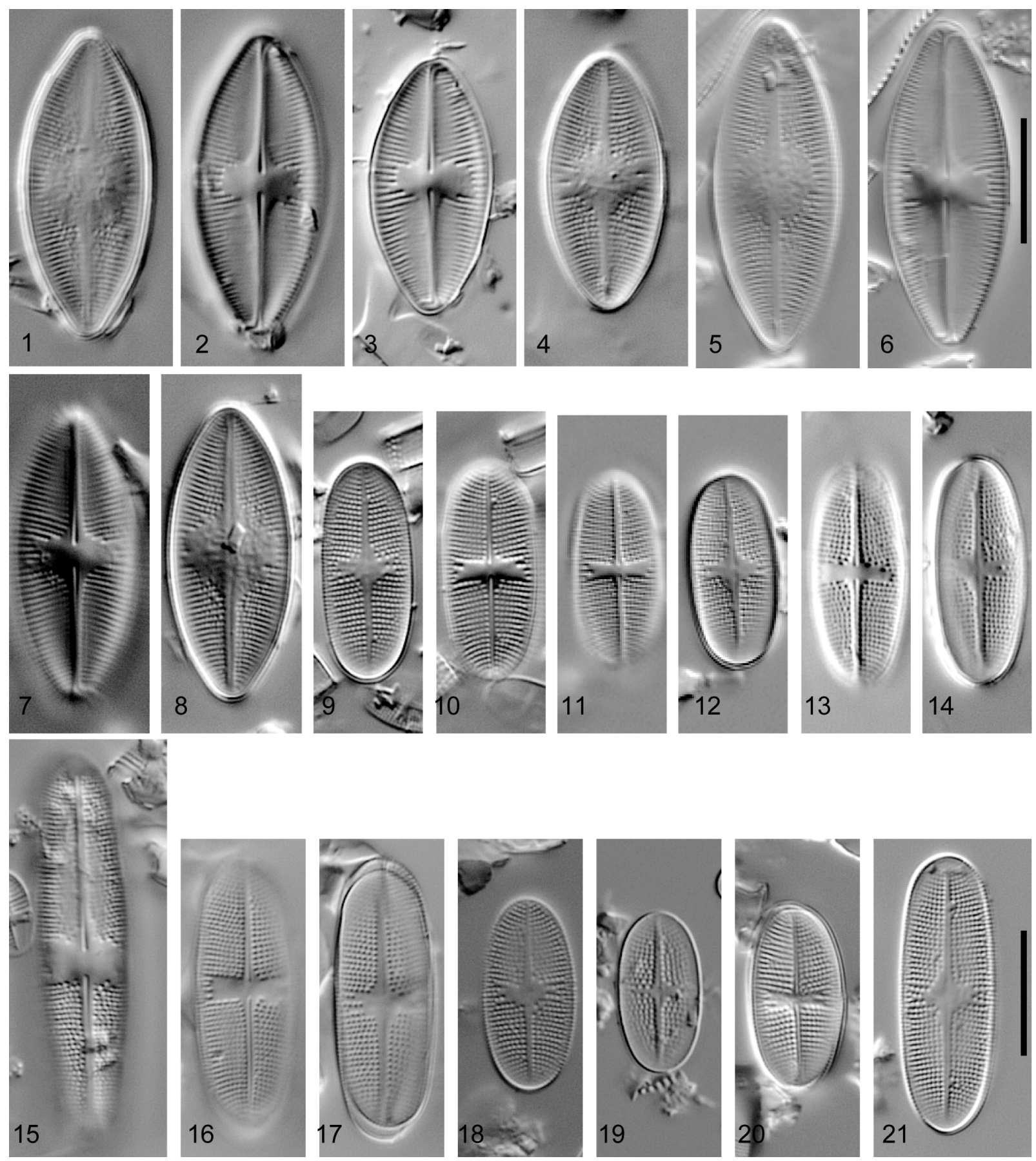

FIGURES 1-21: LM micrographs of Psammothidium species from Snow Lake, Washington Cascades. Figs 1-8. Psammothidium lacustre sp. nov. Figs 1-2. Holotype specimen, slide ANSP GC64860. Figs 9-21. Psammothidium alpinum sp. nov. Figs 9-10. Holotype specimen, slide ANSP GC64862. Scale bar $=10 \mu \mathrm{m}$. 
Etymology:- specific epithet refers to the occurrence of the new species in a lacustrine environment.

The species with the closest morphological features to Psammothidium lacustre is $P$. helveticum (Figs 32 34). Psammothidium lacustre has much larger size, with valve width greather than $8 \mu \mathrm{m}$, and more acute valve ends compared to P. helveticum. SEM investigations (Figs 35-39) revealed that the proximal raphe endings are internally slightly deflected in opposite directions (Fig. 36), similarly to P. helveticum (see Bukhtiyarova $\&$ Round 1996, figure 23). The striae extend uninterrupted onto the mantle, and short striae are present near the central area and occasionally in other parts of valve margin (Fig. 38). Areolae have round external foramina and transapically elongated internal openings (Figs 37, 39).

The shape of the axial and central areas on rapheless valves is similar in Psammothidium lacustre and $P$. helveticum, except that the central area is narrower in $P$. helveticum. Internally, the shape of areolae is also different: elongated with rims and grooves in P. lacustre versus round or rectangular in P. helveticum (see Bukhtiyarova \& Round 1996, figure 23). In LM, P. lacustre is relatively easy to separate from $P$. helveticum; $P$. lacustre is larger, has more lanceolate shape, and coarser striae (22-24 versus 23-28) and areolae. Psammothidium lacustre was rare in study lakes $(<1 \%$ relative abundance).

Psammothidium alpinum Potapova \& Enache sp. nov. (Figs 9-21, 40-44)

Valvae linearae ellipticae, ovalis, 6.3-9.1 $\mu$ m latae, 14.6-30 $\mu$ m longae. Raphovalva cum area axialis angusta linearis versus, area centralis rectagularis. Raphe recta poris centralibus unciformis, termini distale punctiformis. Araphovalva cum area axialis angusta, area centralis circularis, irregularis, 1/2 valvae lata. Striae transapicales paulo radiatae, 22-25 in $10 \mu \mathrm{m}$ cum striae breviores intercalares. Areolae rotundae, grossae, 25 in $10 \mu \mathrm{m}$.

Valves linear-elliptic to oval, 6.3-9.1 $\mu \mathrm{m}$ wide, 14.6-30 $\mu \mathrm{m}$ long. Raphe valve with narrow linear axial area and rectangular-irregular central area. Raphe straight with hook-like proximal pores, drop-shaped distal endings (Figs $10,11,13,15,16,20)$. Rapheless valve with narrow axial area, irregular, rounded central area, occupying about $1 / 2$ of valve breadth (Figs 9, 12, 14, 17-19, 21). Transapical striae slightly radiate, 22-25 in $10 \mu \mathrm{m}$, with shortened marginal striae present (figs 41, 43). Areolae coarse, round, 25 in $10 \mu \mathrm{m}$ (Fig. 44).

Type:-USA. Washington: Cascade Mountains, Snow Lake, $46.7576^{\circ} \mathrm{N}, 121.6982468^{\circ} \mathrm{W}$, lake sediment $(2-2.5$-cm depth core interval; lake maximum depth $9.75 \mathrm{~m}$ ), collected 07 October 2009, collection WACA019, (Circled specimen (Figs 9, 10) on slide GC64862, accession \#GC64862 (ANSP!), holotype, designated here; circled specimens on slide GC64863 (ANSP!) and slide 84223 (CANA!), isotypes, designated here).

Etymology:- -specific epithet refers to the occurrence of the new species in alpine, high elevation lakes.

Psammothidium alpinum is similar to P. bioretii (Germain 1957: 85) Bukhtiyarova et Round (1996: 9) in valve size and possession of relatively coarse areolae. It differs from $P$. bioretii by having more elongate, linear-elliptical valve shape with nearly parallel sides, and a straight central sternum (versus diagonal in $P$. bioretii). In SEM (Figs 40-44), P. alpinum displays a characteristic doublet of smaller areolae at the valve/ mantle junction and around the mantle (Figs 40,42). On raphe valves, the central area nearly reaches the valve margin and is bounded by $4-8$ short striae. The raphe has characteristic hook-like widely spaced proximal endings (Fig 40) that deflect in the same direction externally (Fig. 40) and opposite internally (Fig. 41). While $P$. bioretii has terminal raphe fissures curved to opposite sides, $P$. alpinum lacks terminal fissures, and distal external raphe endings are drop-shaped and do not expand beyond the last stria (Fig. 41). Similar to P. bioretii, P. alpinum has coarse, round areolae visible in LM; a row of coarser areolae border the sternum and central area in LM (Figs 10,11) and a double row of finer areolae bordering the valve face-mantle junction is visible in SEM (Figs 40, 42). Short intercalary striae are present along the valve margin and expand on the mantle (Figs 41, 43). Psammothidium alpinum has similar valve shape as P. chlidanos (Hohn et Hellerman 1963: 273) Lange-Bertalot (1999: 285) but it can be easily distinguished by its coarser striae and areolae visible in LM.

P. alpinum was present in Hidden Lake NOCA (bottom sample, $2 \%$ relative abundance) and very rare in top samples from Snow and Stiletto lakes. 
Valvae ellipticae, 5.6-6 $\mathrm{m}$ latae, 11.7-15 $\mu \mathrm{m}$ longae. Raphovalva cum area axialis linearis, area centralis transapicalem rectagularis vel ovalis, 2/3 valvae lata. Raphe recta cum poris proximales paene expansae, in sulci, cum terminis distales simplices. Araphovalva cum area axialis ad apicem angusta, versus centro expansa, rhombico-lanceolata, 2/3 valvae lata. Striae transapicales paulo radiatae, 26-28 in 10 um in araphovalva, 30-32 in $10 \mu \mathrm{m}$ in raphovalva.

Valves elliptical, 5.6-6 $\mu \mathrm{m}$ wide and 11.7-15 $\mu \mathrm{m}$ long. Raphe valve with linear axial area, central area transapically rectangular to oval occupying $2 / 3$ of the valve breadth. Raphe with proximal pores slightly expanded, located in grooves, and with simple distal endings (Figs 23, 25, 27, 28). Rapheless valve with axial area narrow at apices and widening towards valve centre in a rhombic-lanceolate shape, occupying 2/3 of the valve breadth (Figs 22, 24, 26, $29,30)$. Striae slightly radiate, $26-28$ in $10 \mu \mathrm{m}$ on rapheless valve, $30-32$ on raphe valve.

Type:- USA. Washington: Cascade Mountains, Snow Lake, $46.7576^{\circ} \mathrm{N}, 121.6982468^{\circ} \mathrm{W}$, lake sediment $(2-2.5-\mathrm{cm}$ depth core interval; lake maximum depth $9.75 \mathrm{~m}$ ), collected 07 October 2009, collection WACA019, (Circled specimen (Figs 22, 23) on slide GC64864, accession \#GC64864 (ANSP!), holotype, designated here; circled specimens on slide GC64865 (ANSP!) and slide 84224 (CANA!), isotypes, designated here).

Etymology:- specific epithet refers to the name of the lake (Snow Lake) from where the species was found and described.

Psammothidium nivale is distinguished from other Psammothidium species by characteristic coarser striae and areolae on rapheless valve compared to raphe valve. The linear axial area on raphe valves widens slightly near the valve center, and the transapically rectangular to oval central area is bounded by $4-5$ shortened striae. External proximal raphe endings are located in grooves, which gradually widen toward valve center. External distal raphe endings are drop-shaped and do not extend beyond the last stria (Fig. 45). Characteristic coarse areolae on rapheless valves have the appearance of transapically elongated slits in SEM (Figs 47-48).

In the SEM, the shape of the areolae - transapically elongate-resemble those of $P$. subatomoides in SEM. However, $P$. nivale is distinguished from the latter species by all other valve characteristics: more elongated shape of the valve and larger size, shape of central area on both raphe and rapheless valve and clear dimorphism of raphe and rapheless valve in striae density and areolae size. P. nivale was found in Snow Lake and Hidden Lake NOCA in very low abundance $(<0.25 \%$ relative abundance).
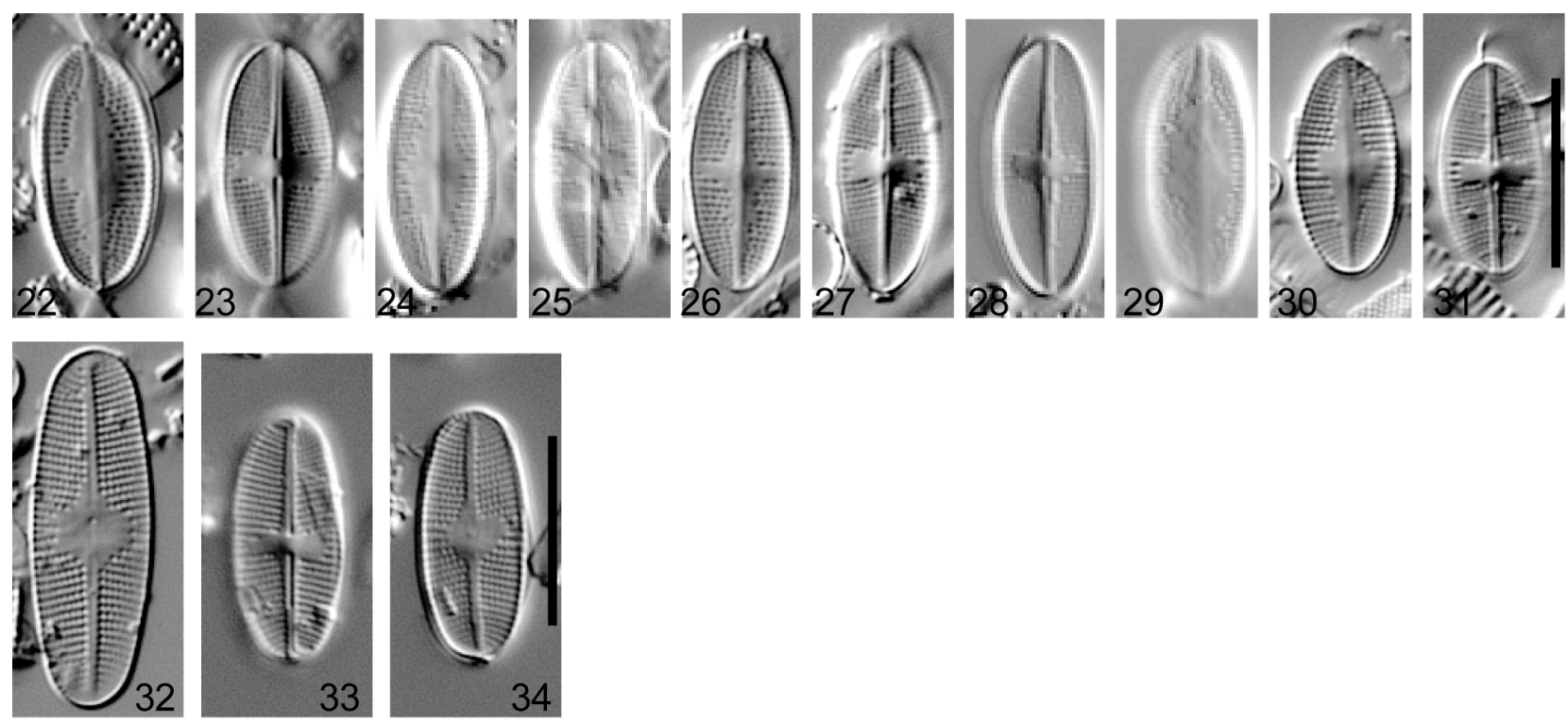

FIGURES 22-34: LM micrographs of Psammothidium species from Snow Lake, Washington Cascades. Figs 22-31. Psammothidium nivale sp. nov. Figs 22-23. Holotype specimen, slide ANSP GC64684. Figs 32-34. Psammothidium helveticum. Scale bar $=10 \mu \mathrm{m}$. 


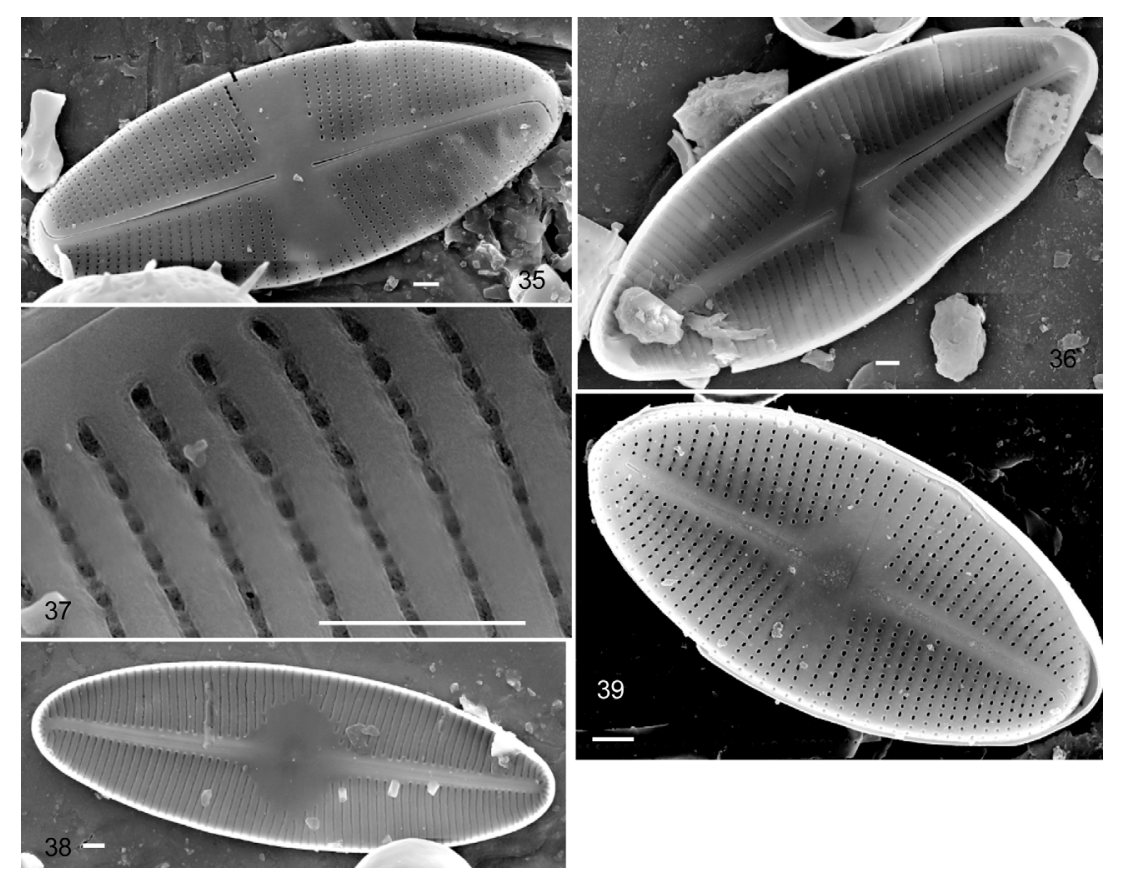

FIGURES 35-39: Psammothidium lacustre sp. nov., SEM. Fig. 35. External view of raphe valve, Hidden Lake NOCA, sample ANSP WACA017. Fig. 36. Internal view of raphe valve, type material, sample ANSP WACA019. Fig. 37. Areolae on internal surface of raphe valve, type material, sample ANSP WACA019. Fig. 38. Internal view of rapheless valve, Hidden Lake NOCA, sample ANSP WACA017. Fig. 39. External view of rapheless valve, type material, sample ANSP WACA019. Scale bars $=1 \mu \mathrm{m}$

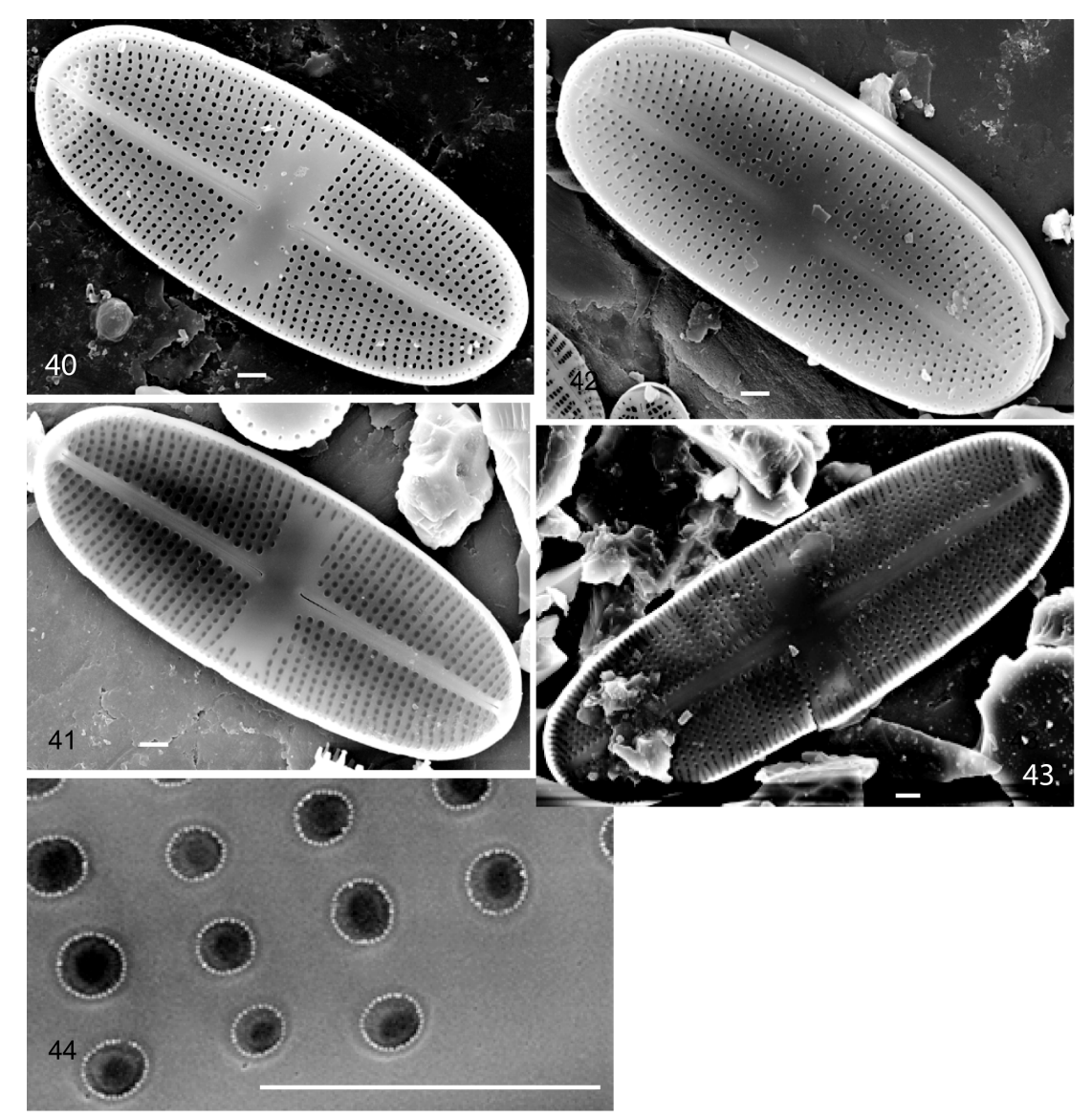

FIGURES 40-44: Psammothidium alpinum sp. nov., SEM. Figs 40-42. Type material, Snow Lake, sample ANSP WACA019 Fig. 40. External view of raphe valve. Fig. 41. Internal view of raphe valve. Fig. 42. External view of rapheless valve. Fig. 43. Internal view of rapheless valve, Hidden Lake NOCA, sample ANSP WACA018. Fig. 44. Areolae on the internal surface of the valve, Snow Lake, sample ANSP WACA001. Scale bars $=1 \mu \mathrm{m}$. 

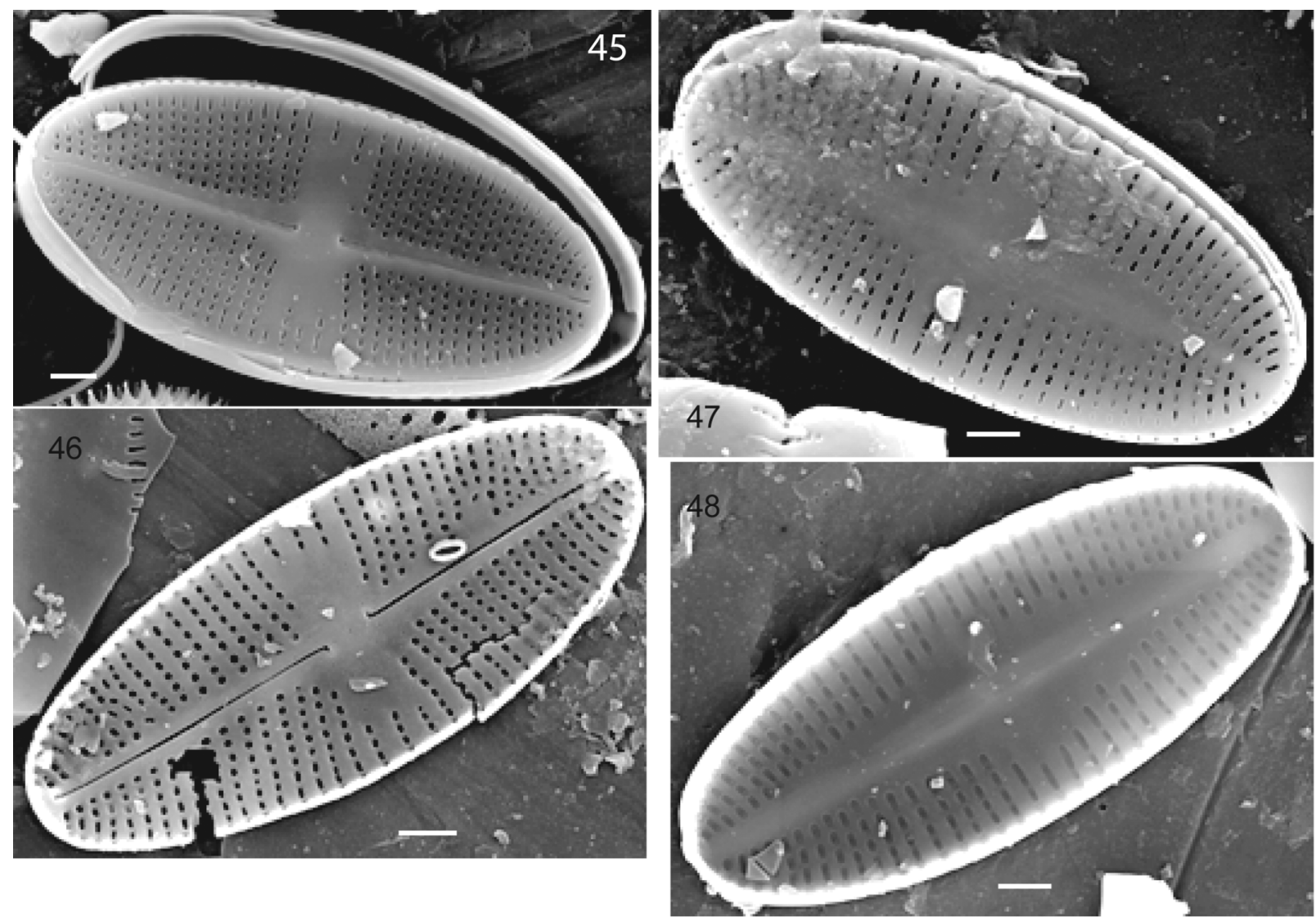

FIGURES 45-48: Psammothidium nivale sp. nov., SEM. Figs 45-47. Type material, sample ANSP WACA019, Snow Lake. Fig. 45. External view of raphe valve. Fig. 46. Internal view of raphe valve. Fig. 47. External view of rapheless valve. Fig. 48. External view of rapheless valve, Hidden Lake NOCA, sample ANSP WACA018. Scale bars $=1 \mu \mathrm{m}$.

\section{Acknowledgements}

Funding for the Washington Cascades project was provided by the United States Geological Survey. Donald Charles and the Ruth Patrick Endowment at the Academy of Natural Sciences provided partial funding to M. Enache for working on the manuscript. We acknowledge the use of the Centralized Research facilities in the College of Engineering at Drexel University, Philadelphia. Use of trade names is for descriptive purposes only and does not imply endorsement by the U.S. Government.

\section{References}

Anonymous (1975) Proposals for a standardization of diatom terminology and diagnoses. Nova Hedwigia, Beih. 53: 323-354.

Aboal, M., Alvarez-Cobelas, M., Cambra, J. \& Ector, L. (2003) Floristic list of non marine diatoms (Bacillariophyceae) of Iberian Peninsula, Balearic Islands, and Canary Islands. Updated taxonomy and bibliography. In: A. Witkowski (ed.), Diatom Monographs. A.R.G. Gantner Verlag K.G., 4: 639 pp.

Bukhtiyarova, L. \& Round, F.E. (1996) Revision of the genus Achnanthes sensu lato section Marginulatae Bukht. Sect. nov. of Achnanthidium Kütz. Diatom Research 11:1-30.

http://dx.doi.org/10.1080/0269249X.1996.9705361

Carter, J.R. (1963) Some new diatoms from British waters. Journal of the Quekett Microscopical Club 29(8): 199-203.

Cleve, P.T. \& Grunow, A. (1880) Beiträge zur Kenntnis der arktischen Diatomeen. Kungliga Svenska Vetenskapsakademiens Handlingar 17(2): 1-121.

Flower, R.J. \& Jones, V.J. (1989) Taxonomic descriptions and occurrences of new Achnanthes taxa in acid lakes in UK. 
Diatom Research 4(2): 227-239.

http://dx.doi.org/10.1080/0269249X.1989.9705072

Germain, H. (1957) Achnanthes bioreti n.sp., diatomée nouvelle. Bulletin de la Société Botanique de France 104 (suppl.): 85-86.

Hohn, M.H. \& Hellerman, J. (1963) Taxonomy and structure of diatom populations from three eastern North American rivers. Transactions of the American Microscopical Society 82: 250-329. http://dx.doi.org/10.2307/3223932

Hustedt, F. (1933) Die Diatomeenflora von Poggenpohls Moor bei Dötlingen in Oldenburg. Abhandlungen und Vorträge der Bremen Wissenschaftliche Gesellschaft 8/9: 362-403.

Lange-Bertalot, H. (1999) Neue Kombinationen von Taxa aus Achnanthes Bory (sensu lato). Iconographia Diatomologica 6: 276-289.

Round, F.E., Crawford, R.M. \& Mann, D.G. (1990) The Diatoms. Biology and morphology of the genera. Cambridge University Press, Cambridge, $747 \mathrm{pp}$.

Schmidt, A. (1936) Atlas der Diatomaceen-kunde. Leipzig. O.R. Reisland Series VIII (Heft 101-102): pls. $401-408$.

U.S. Geological Survey (2006) Collection of water samples (ver. 2.0): U.S. Geological Survey Techniques of WaterResources Investigations. Book 9, chap. A4. September. Available from: http://pubs.water.usgs.gov/twri9A4/ (Accessed 15 January 2010)

Wilde, F.D., Radtke, D.B., Gibs, J. \& Iwatsubo, R.T. (eds.) (2004) Processing of water samples (version 2.1): U.S. Geological Survey Techniques of Water-Resources Investigations. Book 9, chap. A5. April. Available from: http:// pubs.water.usgs.gov/twri9A5/ (accessed 15 January 2010). 